\title{
Capability Brown, Royal Gardener and Placemaker in Northern Europe
}

\author{
Jan Woudstra and Jonathan Finch
}

Being, without doubt, Britain's most celebrated landscape designer, Lancelot 'Capability' Brown (1716-83) is synonymous with the internationally recognised 'English landscape style'. Since his heyday during the second half of the eighteenth century, Brown has been mythologised for his ability to envision the capabilities of both house and landscape for improvement. This myth continues to sustain an international reputation. Critics, however, have, over the same period, complained about his landscapes being bare, smooth, and bald. Later he was accused of destruction, of being the vandal who destroyed the formal garden. ${ }^{1}$ His main contemporary opponent was Sir William Chambers, whose thinly veiled criticisms in his Dissertation on Oriental Gardening (1772) not only reflected envy but were politically motivated. ${ }^{2}$ Successive generations have built on these historic arguments and there has been a tendency towards polarised positions of either unquestioning support or ill-considered criticism. The tercentenary celebrations of his birth provided a magnificent opportunity to pause and review aspects of his life and career that were pertinent to deepening our understanding and correcting our perceptions of the man, his work, and his legacy. However, much (but not all) of the review and new work undertaken under the auspices of Brown's tercentenary simply amplified existing positions. Now, in the aftermath of those celebrations, the elusiveness of Brown the man is still very apparent. His hand is distributed across a wide area of the country but diffused by his business system, which saw his team of trusted associates both deliver and extend the reach of 'his' landscape style. It is also apparent that 'his' style was somewhat lost in translation as it crossed, belatedly, to continental Europe over the following century. The new tercentennial work did, however, expose areas where innovation could contribute substantially, and around which this volume has been loosely structured. Three such areas of importance were identified - the significance of Brown's position as royal gardener; the professionalisation of the trade of place-making and within it Brown's modus operandi; and, finally, the perception and reception of Brown and his work, and how these evolved over time, both in Britain and abroad.

${ }^{1}$ Law, E. (1891). A history of Hampton Court Palace (Vol. III, p.297) London: George Bell.

${ }^{2}$ Chambers, W. (1772). A dissertation on oriental gardening. London.

How to cite this book chapter:

Woudstra, J. and Finch, J. 2020. Capability Brown, Royal Gardener and Placemaker in Northern Europe. In Finch, J. and Woudstra, J. (Eds.), Capability Brown, Royal Gardener: The business of place-making in Northern Europe, pp. 199-204. York: White Rose University Press. DOI: https://doi.org/10.22599/CapabilityBrown.n. CC BY-NC 4.0 


\section{The Royal Gardener}

Brown's career as a gardener and the feted position as royal gardener were heavily influenced by contemporary politics, and particularly his relationship with, or rather envy from, William Chambers, the architect and designer of gardens, who also aspired to this royal position. Chambers had taught the royal children and was therefore better placed to receive an offer for the post, and he did manage to delay it for Brown, who, through the interference of the prime minister in 1764, was ultimately placed at Hampton Court Palace, rather than being put in charge of all royal gardens. While Brown did get the opportunity to re-shape Richmond Gardens, owned by the king, other royal commissions passed him by, seemingly in favour of Chambers. Additionally, there were limited resources available for Hampton Court, which was no longer used as a primary royal residence and where the formal and constrained nature of the site and gardens appeared at odds with Brown's vision, but legend has it that he declined to improve the gardens 'out of respect to himself and his profession. ${ }^{3}$ While being in service provided Brown with the attendant frustrations, his position as a royal gardener enhanced his status, and put him in an enviable position wherein he was also able to continue carrying out private commissions. On one level the substantial and regular income would have been a considerable bonus to Brown, who was constantly trying to manage an erratic cash flow and a huge network of employees and associates working at sites across the country. On another, his position at Hampton Court placed him socially and physically at the heart of the most affluent and profligate networks in the country, fed by global trade and government sinecures, and manifested in landownership. It is at court that we see a side to Brown which rarely surfaces elsewhere. He was confronted by the acerbic campaign of Chambers to do him down, based on snobbery and professional jealousy, and yet Brown and his supporters readily displaced the Greenings, who had become well-established features of the court-related nursery scene. The views of the royal gardens also reveal the diversity of landscape styles that co-existed in London and under the banner of the royal family, and the fact that Brown was responsible for some - but demurred from changing them or even clipping the topiary, sheds unexpected light on his outlook on landscape and gardens, as well as hinting at how he prioritised his own private commissions, rather than engaging with the prolonged and potentially arduous task of radical change within the court.

\section{The Place-Maker}

Brown learned the business of place-making in practice, probably first as an estate steward or land manager, and then particularly at Stowe, where he implemented schemes devised by those regarded as at the top of the profession, and was able to learn from their mistakes, such as a failed attempt to create a lake there, providing the opportunity for a secluded Grecian valley, thus turning a negative into a positive. His ability to do this reveals another of his skills, namely the fact that he was an efficient communicator and good company, able to hold his own and convince others, across a wide social and professional spectrum. He was also a good businessman, organising his affairs in such a way that he worked with a number of foremen, trained or tested by him, who were given responsibility to run parts of the business independently while he travelled the country at certain times of the year, meeting both clients and workmen. During these journeys, work would be commissioned, while the organisation of it would ensure the schedule of works was accommodated within busy nationwide programmes of work with a clear focus on completion. His system sustained his growing business through both lean periods and those of unrivalled success, in a manner that other early contemporaries, such as Richard Woods, could not emulate. It may not be surprising, therefore, that, as his success grew, as his business expanded, as patrons became increasingly familiar with the perception of what a Brown landscape should look like, and as imitations proliferated from the hands of his former associates, so the 'Brownian' landscapes became slightly formulaic.

Brown's vision of place-making included all facets, not just the creation of classical parks but also pleasure grounds, kitchen gardens, and buildings, stable blocks and other outbuildings, menageries, ice houses, and sometimes even the main house itself. Architecture was an important element within Brown's portfolio of skills and also within his vision of landscape in a manner which is often lost amidst modern scholarship of landscape or architecture. In order to fulfil the increasing demand for amenities within the estate, it was important to

${ }^{3}$ Law, E. (1891). A History of Hampton Court Palace (Vol. III, p. 296) London: George Bell. 
articulate spaces for various functions and purposes. While much of this was done by vegetation, with belts and clumps, many of the projects also included re-shaping the land, and therefore extensive earth movement, often associated with the creation of lakes. These and other works were prepared through surveys of various sorts, stipulated on drawings and in contracts, with the workforce being paid weekly, but suppliers only at the end of the commission. Detailed administration - inventories of goods and material, bills, and vouchers - facilitated the smooth running of projects. Within the office there was a clear work division, with shared responsibilities; John Spyers was a draughtsman and surveyor, but Samuel Lapidge was trained in all aspects of the business and was thus destined to be Brown's successor. ${ }^{4}$

A major part in the success of Brown's business was the way in which it was marketed. The acknowledgement in 1750 of Lord Coventry of Croome Court typifying Brown as being someone to recognise the 'capabilities' of a site led to his sobriquet of 'Capability' Brown, which then provided a magisterial marketing ploy, as simple and to the point, clearly distinguishable, setting him apart from his competitors, ultimately recognisable and visionary. Today this name continues to appeal to the imagination, and is as effective now as it was then, with it often being the only name of a British landscape designer people recognise. This is notable because Brown left so little in the way of documentary or published accounts of his practice. He never published a theory or discourse on landscape design, nor did his business model facilitate an accurate record of the sites he had worked at, such was the diversity of teams and methods deployed. Brown left us only plans and bank accounts from which to reconstruct his vision and impact on the landscape. This is in contrast to his would-be successor, Humphry Repton. It is telling in terms of how far the business of place-making had changed between Brown setting up business in 1751 and Repton doing the same in 1788, that Repton marketed himself through illustrated theoretical publications, business cards, which promoted a new name for the profession - that of landscape gardener - and the production of his bespoke 'Red Books' for key sites and commissions, which contained beautifully hand-painted 'before and after' slides to illustrate his proposals. For Repton, his clients had changed, the economic situation had changed, the profession had changed, everything had changed after Brown. Yet it was Repton who defended Brown's reputation from the attacks launched by Price and Knight and it was J. C. Loudon's re-publication of Repton's works in the mid-nineteenth century that spread the English style - still associated with Brown - across Europe and beyond.

\section{European Context}

For much of the eighteenth century garden design in continental Europe had continued to be dominated by formality in the style of André le Nôtre, with some Anglo-Chinese style gardens with their sinuous designs appearing over time, but usually within a formal frame. The jardin anglais did not really become a major trend until after the 1789 French Revolution, after the dissolution of royal property that was later refashioned to appeal to the people. It was here that the English garden redefined its meaning through its associations with the Enlightenment. The informality in design and lack of clipping was seen as liberating; the lack of a main axis and central position of the main building as a departure from the absolutist regime. Thus the English garden could be interpreted as more egalitarian. Yet until his death in 1783 such associations could and would not have occurred to Brown, who was a practical man, not a philosopher.

While he did produce designs for some sites on the Continent in the Germanic countries and Southern Netherlands (Belgium), Brown concentrated on his work in Britain, even turning down the chance to work in Ireland because, he quipped, he had not finished with England. ${ }^{5}$ It would not have been possible to use his successful modus operandi on sites there nor control a workforce, thus he sensibly concentrated his efforts at home. Given his reluctance to engage abroad, the lack of a personal treatise further limited his reputation on the Continent. This is where Chambers triumphed, albeit briefly; his books were translated into French and they promoted the Anglo-Chinese style of garden-making, less sophisticated than Brown's classical landscapes perhaps, but more intricate and easier to translate to the smaller scale of European elite landscapes. Yet by the end of the eighteenth century there were designers in both France and Germany able to design Brownian-style landscapes, often adapting methodologies to fit in with local sensibilities or practices.

\footnotetext{
${ }^{4}$ Dedinkin, M. \& Jacques, D. (2016). The Hampton Court albums of Catherine the Great. London: Fontanka.

${ }^{5}$ See Brown, J. (2011). The omnipotent magician, Lancelot 'Capability' Brown 1716-1783 (p. 5). London: Chatto and Windus.
} 
During the nineteenth century Brown gradually became included in historiographies, but often only in the sequence of Kent, Brown, and Repton as holding the standard of English landscape gardening. He also occurred within retellings of the Picturesque debate, where he features as an antiquated practitioner, despite the fact that his practices became more and more commonplace, as mediated through Repton. As a result his design principles became the mainstay of landscape design almost imperceptibly and through the offices of others. Brownian principles were applied to landscapes, cemeteries, parks, and gardens, private and public, not only in Europe, but also elsewhere in the world and became the modus operandi of the profession until well into the twentieth century. Remarkably, it was only after this wholescale adoption of his principles was challenged in the modernist era that a revival of his reputation began. Dorothy Stroud had begun her biography of Brown at the outbreak of the Second World War, when promoting landscapes that captured an historic sense of Englishness served a national purpose. ${ }^{6}$ It was not published until the end of the Second World War, however, when a more general anglomania spread across Europe, and its publication revived his reputation both at home and abroad. His work was not only appreciated afresh but also became assimilated in post-war landscape design, as open and flowing; it additionally became celebrated as that of a landscape designer who managed to bridge landscape and architecture. ${ }^{7}$ Now, at the beginning of a new fractured era in Anglo-European affairs, Brown's position as a national 'place-maker' may be redrawn, repositioned, and questioned again.

\section{Future Research}

Much has been accomplished in the study of Brown since Stroud's biography and in particular over the last twenty-five years, culminating with the wide public engagement generated by the celebration of his tercentenary in 2016. We now have a better, if not substantial, picture of the man, and a clearer narrative of his life and work. We also have a better understanding of the design objectives, uses, and appearance of his landscapes, but these advances have served to illuminate where more work needs to be done.

There is, for example, a clear and urgent need for a critical study of all Brown's known garden plans, with analysis of the palaeography to identify the different hands that produced them, including an online repository for high resolution digital copies, linked to other mapping data, aerial views, and LIDAR images, and eventually to a raft of contemporary documentary sources, such as visitors' accounts and estate records. ${ }^{8}$ This would be a fitting partner to the accounts, the analysis of which has shed so much new light on Brown, his methods and his sites. Such a comprehensive set of accessible documentary records would ignite a new generation of research, tackling new questions.

Similarly, without a greater understanding of the work of Brown's contemporaries it will be impossible to establish Brown's unique characteristics and contribution to landscape design. It is currently very problematic to determine what constituted Brown's particular style, what the various features were, how they were intended to be managed and maintained, and how this changed over his lifetime. These are all issues that are particularly relevant to those involved in the conservation of eighteenth-century parks and gardens, as many now have little original (planting) fabric left. Today we are being confronted with possibly far-reaching environmental change, which presents us with a whole range of additional issues, so it is important to understand the ecology of the parkland landscapes that Brown envisioned as well as their aesthetics. ${ }^{9}$ Their role, as protected historic green spaces, will become increasingly critical to the management and survival of complex ecosystems, particularly in the face of climate change and variability.

The availability of Brown's plans would also enable research into how earlier traditions influenced his designs; we now have a greater understanding of how the aesthetics of his parkland were influenced by medieval parks and wood-pasture. The shrubberies in his designs evolved from early eighteenth-century wilderness planting, with perhaps the innovation being the outline or shape enabling the creation of flowing spaces. Whether Brown adapted his planting and the choice of species to the particular conditions he was working with, or the client he

\footnotetext{
${ }^{6}$ Stroud, D. (1975). Capability Brown (p. 7).

7 Buruma, I. (1999). Voltaire's coconuts: Or anglomania in Europe. London: Weidenfeld and Nicolson.

${ }^{8}$ Only an initial basic listing of Brown's plans exists: Rutherford, S. \& Evans, C. (2018). Capability Brown's plans: A reference catalogue of design plans and surveys drawn by Brown or his office (c. 1750-83) (Research Report Series 5). Swindon: Historic England.

${ }^{9}$ See for example, Rotherham, I. \& Handley, C. (Eds) (2017). What did Capability Brown do for ecology? The legacy of biodiversity, landscapes and nature conservation. Sheffield: Wildtrack.
} 
was working for, is also something that would benefit from further research. Yet it is precisely because we have so little contemporary evidence of this aspect in his parks that additional work is required in order to establish his originality and innovation.

Similarly, further research may give additional evidence on the uses and land uses within parks; the way they were grazed or mown, used for hunting and shooting, for pleasure rides and games, for fishing and boating. All these would have left their evidence in design, management, and appearance. Recent research, including that led by Felus, has revealed various aspects that have previously been neglected, but there remains much to be done in order to understand how and by whom these landscapes were experienced, with a particular emphasis on gendered differences. Also, we know little about the horticultural operations at the places Brown worked, but particularly at Hampton Court Palace. In this instance it would benefit from detailed and contextual case studies from the perspective of the manager and designer, with reference to the needs of the client and an understanding of the challenges of the site.

Armed with these new understandings it is opportune to reintegrate Brown into multi-disciplinary studies of the eighteenth century. More work needs to be done on Brown's place within the world of business to establish how he developed his model of networked associates, where previously family connections had been the dominant bonds of trust, such as with the Greenings. How his model differed from other businesses in his control of cash flow and investments over a period of turbulent and unpredictable financial changes would help shed light on the evolving sense of professionalism evident in Repton's different approach. Roderick Floud has brought to bear the forensic eye of the economic historian, and it is now clear just how expensive Brown's schemes were, posing important questions about how Brown's landscapes were financed, which in turn draws out fundamental questions about the basis and fluidity of late eighteenth-century polite society. ${ }^{10}$ Floud argues that the creation of designed landscapes was an important motor for technological innovation, employment, and the national economy more generally, but also that they were embedded within the expanding colonial economy. It would therefore be interesting to place Brown's business model within the context of cultural industries which furnished polite society during the late-eighteenth century, breaking out from a simple consumerist model. Indeed, the manner in which scholars have had to approach Brown as an elusive figurehead might in itself provide a useful model for how to research landscape arts more widely in the period, paying attention to the practical issues of partnerships, contracts, labour gangs, and remote fieldwork.

One of the key issues in determining meaning within Brownian classical landscapes is to explore more critically how they related to the values and aspirations of his clients at a particular historical moment. The link is clearly significant, but we are only at the beginnings, as Williamson has pointed out, of understanding how it related to the wider shaping of aristocratic material worlds and changing perceptions of power and landscape. Brown needs to be contextualised within English influences more generally, and the English landscape style specifically, in relationship to 'improvement' and agricultural practices and what came to be known as the landscape garden more specifically. One of the main avenues that is emerging is the need for an analysis of the making and remaking of these landscapes from the perspective of 'improvement', placing them within the contemporary agricultural and social context, in combination with an exploration of the main sources of funding that enabled owners to afford these landscaping schemes.

Finally, and not least, Brown's influence on the European continent and beyond is still poorly understood as the evidence is far from clear, or substantial, and the chronologies need to be more critically and accurately determined. Much more research is required in order to identify this within sociopolitical and art historical perspectives, in various countries and within specific themes. It is clear that as well as contemporary admiration for Brown, such as from Catherine the Great, and considerable interest from aristocratic and horticultural tourists, there was a much greater adherence to the formal style on the Continent, even though the role of the aristocracy and their political influence varied greatly across the region. Brown's legacy through the published works of Repton and others is something that requires greater scrutiny both in Europe and the New World, where again he had both his adherents and his detractors. It is perhaps here, in the global reception of Brown, that the key to his success - both at home in the eighteenth century and abroad in the nineteenth - might be determined more clearly.

It is clear from the new studies presented here, and by recent scholarship prompted by the celebrations of Brown's tercentenary in 2016, that there is still great potential for new understanding about the remaking of the

${ }^{10}$ Floud, R. (2019). An economic history of the English garden. London: Allen Lane. 
landscape over the long eighteenth century, an understanding to which Brown is central. As we embark on the fourth century since Brown's birth, so we embark on a new era of research. There is clearly more work to do in exploring Brown's relationship with this contemporaries, which will emerge from detailed studies of sites across the country. There is huge potential in the existing visual, cartographic, and documentary sources available, as well as the hope that more will emerge from family, estate, and business archives. However, the new challenge is to draw away from traditional narratives based on familiar key sites, and to resist the pendulum swing of assessing Brown as a genius or a self-publicist. There needs to be a new interpretation of the eighteenth-century landscape which broadens its purview socially, economically, and culturally to capture more of the subtle complexities of the landscape as it was imagined, experienced, and perceived. From an historical perspective it is clear that Brown's reputation will not only continue to be reappreciated and evolve but also endure.

This study has sought to address three key lacunas in his biography - his role as Royal Gardener, his working methods, and his reception and impact across Northern Europe. In doing so it has not only redefined Brown as running a complex metropolitan business embedded within the seat of power; it has placed him in a much broader national and international context and acknowledged his links to the global economy. Only by exploring those who worked around him, with him, and even against him is it possible to gain a greater understanding of his achievements, his significance, and his landscape legacy. It is one of the paradoxes of historical and landscape research that we are reliant upon the landscapes he created and the attitudes and comments of those around him, in order to delineate Brown and his vision. Brown is apt to disappear from view just as we put in place the scholarship to illuminate his personality, his ideas, and his landscapes.

\section{Select Bibliography}

A select bibliography is available at the end of this volume, or at: https://doi.org/10.22599/CapabilityBrown.o. 